\title{
Cost of Transformation among Primary Care Practices Participating in a Medical Home Pilot
}

\author{
Grant R. Martsolf, PhD, MPH, RN ${ }^{7}$, Ryan Kandrack, $B S^{7}$, Robert A. Gabbay, MD, PhD ${ }^{2,3}$, and \\ Mark W. Friedberg, MD, MPP $3,4,5$
}

'RAND Corporation, Pittsburgh, PA, USA; ${ }^{2}$ Joslin Diabetes Center, Boston, MA, USA; ${ }^{3}$ Harvard Medical School, Boston, MA, USA; ${ }^{4}$ RAND Corporation, Boston, MA, USA; ${ }^{5}$ Division of General Internal Medicine, Brigham and Women's Hospital, Boston, MA, USA.

\begin{abstract}
BACKGROUND: Medical home initiatives encourage primary care practices to invest in new structural capabilities such as patient registries and information technology, but little is known about the costs of these investments.
\end{abstract}

OBJECTIVES: To estimate costs of transformation incurred by primary care practices participating in a medical home pilot.

DESIGN: We interviewed practice leaders in order to identify changes practices had undertaken due to medical home transformation. Based on the principles of activity-based costing, we estimated the costs of additional personnel and other investments associated with these changes.

SETTING: The Pennsylvania Chronic Care Initiative (PACCI), a statewide multi-payer medical home pilot.

PARTICIPANTS: Twelve practices that participated in the PACCI.

MEASUREMENTS: One-time and ongoing yearly costs attributed to medical home transformation.

RESULTS: Practices incurred median one-time transformation-associated costs of $\$ 30,991$ per practice (range, \$7694 to $\$ 117,810$ ), equivalent to $\$ 9814$ per clinician $(\$ 1497$ to $\$ 57,476)$ and $\$ 8$ per patient (\$1 to $\$ 30)$. Median ongoing yearly costs associated with transformation were $\$ 147,573$ per practice (range, $\$ 83,829$ to $\$ 346,603)$, equivalent to $\$ 64,768$ per clinician $(\$ 18,585$ to $\$ 93,856)$ and $\$ 30$ per patient (\$8 to $\$ 136)$. Care management activities accounted for over 60\% of practices' transformation-associated costs. Per-clinician and perpatient transformation costs were greater for small and independent practices than for large and system-affiliated practices.

LIMITATIONS: Error in interviewee recall could affect estimates. Transformation costs in other medical home interventions may be different.

CONCLUSIONS: The costs of medical home transformation vary widely, creating potential financial challenges for primary care practices-especially those that are small and independent. Tailored subsidies from payers may help practices make these investments.

PRIMARY FUNDING SOURCE: Agency for Healthcare Research and Quality

KEY WORDS: patient-centered medical home; primary care; costs.

Received August 3, 2015

Revised September 29, 2015

Accepted November 16, 2015

Published online December 29, 2015
$\mathrm{J}$ Gen Intern Med 31(7):723-31

DOI: $10.1007 / \mathrm{s} 11606-015-3553-6$

(c) Society of General Internal Medicine 2015

\section{INTRODUCTION}

Transforming primary care practices into medical homes-also known as patient-centered medical homes (PCMHs) - is increasingly seen as a way to enhance primary care. In medical home transformation, practices can make many changes, including adoption of new structural capabilities such as patient registries, care managers, and information technology. Evidence to date on medical home interventions - studies that compare intervention participants to non-participants-is mixed, with inconsistent effects on patient care. ${ }^{1-8}$ However, studies with a different design-those comparing practices that have achieved medical home recognition to those that have not-have found more consistent associations between practice transformation and improvements in the quality and efficiency of care, patient experience, and provider satisfaction. ${ }^{9-14}$ This apparent discrepancy might be explained by barriers that prevent some intervention participants from successfully transforming into medical homes. For example, such transformation may require substantial financial investments that are beyond the reach of some primary care practices.

To support practice transformation, a variety of public and private payers have provided financial and in-kind resources (e.g., on-site care managers) to practices participating in medical home interventions. ${ }^{15,16}$ But within such interventions, there is little published evidence on the size of transformation-associated costs to practices. Without estimates of these costs, payers and policymakers risk under-funding practice transformation, thereby reducing the attractiveness and effectiveness of medical home interventions.

To estimate the costs of transformation among primary care practices participating in a statewide medical home intervention, we interviewed practice representatives, identified the components of each practice's transformation during the intervention, and calculated the corresponding costs. 


\section{METHODS}

\section{Practice Selection}

We selected primary care practices that participated in the first 3 years of the Pennsylvania Chronic Care Initiative (PACCI), a statewide medical home pilot. ${ }^{1}$ The PACCI required each participating practice to achieve recognition from the National Committee for Quality Assurance's Physician Practice Connections-Patient-Centered Medical Home (NCQA PPC-PCMH) program and to participate in technical assistance activities. To support transformation, eight commercial and four Medicaid managed care plans provided enhanced payments to participating practices. These health plans supported the PACCI in four geographic regions - southeast, south central, southwest, and northeast Pennsylvania. The pilot, which was originally designed to run for three years in each region, started on a rolling basis: the earliest start date was June 2008 (southeast region) and the latest was October 2009 (northeast region).

We aimed to select practices with varying levels of structural and functional transformation. To assess structural transformation, we sent a survey to one leader of each practice at baseline and at the end of pilot year 3 (in each region) that queried the presence of capabilities such as patient registries, care managers, information technology, and after-hours access. ${ }^{17}$ Based on survey responses, we calculated each practice's change on an overall structural capability score. To assess functional transformation, we measured changes in each practice's performance on quality (nine measures of chronic disease and preventive care) and costs of care over 3 years using claims data from 8 of the 12 participating health plans.

We then ranked the practices within each demonstration region on their pre- to post-demonstration changes in their structural and functional transformation capabilities, calculated the mean of the three ranks (structural, quality, and cost), and categorized practices in the top tertile as high transformers, those in the middle tertile as moderate transformers, and those in the bottom tertile as low transformers. In other words, high transformers differed from moderate and low transformers in their degree of structural change during the pilot, irrespective of practice capabilities at baseline (i.e., before the pilot began). Details of these transformation assessment methods are available in Appendix A.

We then invited practices to participate in the study, seeking two high transformers and one low transformer in each of the four regions of the pilot. We contacted a total of 22 practices to obtain 12 participants, for a total response rate of 55\%. We offered $\$ 300$ to each practice for participation in the study.

\section{Data Collection and Analysis}

We used the principles of activity-based costing to calculate the costs incurred by primary care practices due to their medical home transformation. ${ }^{18}$
First, we conducted semi-structured interviews with representatives at each physician practice, asking respondents to report changes that the practice made because of its medical home transformation (interview protocol available in Appendix B). Between one and seven respondents participated in each interview; seven of the interviews included multiple participants. Three other participants conferred with other members of the organization, either before or after the interviews, to gather additional information or to confirm aspects of their estimates. For each practice, these respondents included the individual identified by practice leadership as the most knowledgeable about the changes involved in medical home transformation and the costs associated with these changes.

We began the interviews by asking practice representatives to describe how the practice had changed over the course of the medical home pilot. The interview protocol allowed respondents to describe these changes without restriction to a pre-specified list, and for each practice we created a roster of the changes described (e.g., initiating a care management program). Once the respondents verified this roster of changes, we asked them to describe the changes in personnel (e.g., hiring new employees, time spent by existing employees) and non-personnel costs (e.g., investing in new technology) involved in each change. We asked participants to distinguish between one-time costs (e.g., cost of submitting an application for medical home recognition) and ongoing costs, which they continued to incur yearly as a consequence of each change.

Second, after the interviews, we converted personnel estimates into costs using state-level wage rates from the Health Care Group 2014 Staff Salary Survey and the Bureau of Labor Statistics wage data, adding $30 \%$ to each of the hourly wage costs to account for benefits. 19,20

Third, to verify our cost estimates, we created a report for each practice detailing the transformation changes described by the interviewees and the costs associated with each change. We shared each report with interviewees from the corresponding practice, sought comments on the face validity of the cost estimates, and asked for corrections when necessary. Some interview participants shared the cost reports with others in their practice in order to provide further validation for the estimates. We continued to update the cost reports until interviewees provided no additional corrections.

We used these cost reports to estimate the one-time and ongoing costs of transformation across all 12 practices. We grouped all one-time costs into a single category, since most one-time activities were general preparation activities (e.g., developing and documenting internal policies) rather than a particular change in the practice. We divided ongoing costs stemming from each transformation change into five categories: care management, quality improvement, expanded access, information technology (IT), and other activities.

Fourth, we calculated per-clinician costs by dividing total costs by the number of primary care clinicians (physicians, nurse practitioners, and physician assistants) who worked at the practice in a "typical day" during the pilot. To estimate per- 
patient costs, we divided total costs by estimates of the number of patients in the practice's panel during the transformation period (as estimated by interviewees), rounding to the nearest whole dollar. We asked each practice to estimate its overall panel size, which we then divided by the number of primary care clinicians in the practice to calculate the practice's perclinician panel size.

Finally, we categorized practices as either "system-affiliated" (owned by a hospital, health maintenance organization, or a multi-site medical group) or "independent," and as either large (four or more primary care clinicians) or small (fewer than four primary care clinicians). We then compared transformation costs between practices with high versus medium or low transformation, system-affiliated versus independent status, and large versus small size. Due to limited sample size, we did not perform statistical tests of these comparisons.

This study was approved by the RAND Human Subjects Protection Committee.

\section{RESULTS}

\section{Practice Characteristics}

The 12 practices participating in our study had a median of three primary care clinicians and 1562.5 patients per primary care clinician (Table 1). Six participating practices were classified as family medicine or mixed specialty, five were internal medicine, and one was pediatric only; seven were system-affiliated, and five were independent. By design, three practices were located in each of the four PACCI regions. At the end of the 3year pilot in each region, 11 participating practices had achieved NCQA PPC-PCMH recognition at level 3, and one had achieved level 2 recognition.

Participating practices were comparable to non-participants in size, specialty, system affiliation, and NCQA PPC-PCMH level. However, to reach the target sample composition, we needed to invite disproportionate numbers of practices that were low-transforming and located in the south central region, resulting in higher numbers of non-participants with these characteristics.

\section{Description of One-Time Costs}

Participating practices spent a median of $\$ 30,991$ (range, $\$ 7694$ to $\$ 117,810$ ) in one-time costs as part of their medical home transformation, or $\$ 9814$ per clinician (\$1497 to $\$ 57,476$ ) and $\$ 8$ per patient (\$1 to $\$ 30)$ (Table 2). Specific one-time activities included setting up and verifying the accuracy of patient registries, training employees to use quality reporting systems, preparing internal policies and procedures for medical home transformation, and completing medical home recognition applications. Four practices upgraded their information technology systems.
Table 1 Practice Characteristics

\begin{tabular}{|c|c|c|}
\hline & $\begin{array}{l}\text { Participating } \\
\text { practices }(n=12)\end{array}$ & $\begin{array}{l}\text { Invited practices } \\
\text { that declined or } \\
\text { did not respond } \\
(n=10)\end{array}$ \\
\hline & Median (IQR) & Median (IQR) \\
\hline Primary Care Clinicians* & $3(2-4)$ & $4(3.25-5)$ \\
\hline \multirow[t]{2}{*}{ Patients per clinician } & $\begin{array}{l}1562.5 \\
(1193.5-2483.3)\end{array}$ & $\mathrm{NA}$ \\
\hline & $\begin{array}{l}\text { Number of } \\
\text { practices }(\%)\end{array}$ & $\begin{array}{l}\text { Number of } \\
\text { practices }(\%)\end{array}$ \\
\hline \multicolumn{3}{|l|}{ Specialty } \\
\hline Family Practice or Mixed & $6(50 \%)$ & $5(50 \%)$ \\
\hline Internal Medicine Only & $5(42 \%)$ & $2(20 \%)$ \\
\hline Pediatrics Only & $1(8 \%)$ & $3(30 \%)$ \\
\hline \multicolumn{3}{|l|}{ System affiliation } \\
\hline System-affiliated & $7(58 \%)$ & $6(60 \%)$ \\
\hline Independent & $5(42 \%)$ & $4(40 \%)$ \\
\hline \multicolumn{3}{|l|}{ Region } \\
\hline Northeast & $3(25 \%)$ & $2(20 \%)$ \\
\hline Southeast & $3(25 \%)$ & $1(10 \%)$ \\
\hline Southwest & $3(25 \%)$ & $1(10 \%)$ \\
\hline South central & $3(25 \%)$ & $6(60 \%)$ \\
\hline \multicolumn{3}{|l|}{ NCQA PPC-PCMH Level } \\
\hline Level 1 & $0(0 \%)$ & $1(10 \%)$ \\
\hline Level 2 & $1(8 \%)$ & $2(20 \%)$ \\
\hline Level 3 & $11(92 \%)$ & $7(70 \%)$ \\
\hline \multicolumn{3}{|l|}{ Extent of transformation } \\
\hline High & $8(67 \%)$ & $4(40 \%)$ \\
\hline Moderate & $1(8 \%)$ & 0 \\
\hline Low & $3(25 \%)$ & $6(60 \%)$ \\
\hline
\end{tabular}

Note: No differences between columns were statistically significant at the 0.05 level using a Kruskal-Wallis test for the number of clinicians and patients or Fisher's exact test for categorical variables

*Includes NPS, PAs, and primary care physicians

\section{Description of Ongoing Costs}

The median cost of ongoing medical home activities was $\$ 147,573$ per year per practice (range, $\$ 83,829$ to $\$ 346,603$ ), or $\$ 64,768$ per clinician $(\$ 18,585$ to $\$ 93,856)$ and $\$ 30$ per patient ( $\$ 8$ to $\$ 136$ ). Care management activities, which frequently involved hiring one or more care managers or other staff to implement care management initiatives, constituted the greatest share of these ongoing costs. Practices' median yearly care management costs were $\$ 113,031$ (range, $\$ 41,191$ to $\$ 234,547)$, or $\$ 29,457$ per clinician $(\$ 11,420$ to $\$ 78,182)$ and $\$ 16$ per patient ( $\$ 3$ to $\$ 110$ ).

Eleven practices reported instituting new quality improvement (QI) processes, such as generating practice performance reports (e.g., to track Healthcare Effectiveness Data and Information Set [HEDIS] quality measures), instituting reminders to physicians to provide recommended services, and conducting regular QI meetings to discuss ways to improve performance. Practices' median yearly QI activity costs were $\$ 23,734$ (range, $\$ 0$ to $\$ 63,905$ ), or $\$ 5765$ per clinician ( $\$ 0$ to $\$ 29,924$ ) and $\$ 3$ per patient (\$0 to $\$ 26$ ).

Only four practices reported expanding patient access to care. Three practices increased their hours, providing office visits for an additional 7.5 to 20 hours per week, while the fourth practice increased the number of daily appointments available by changing its scheduling procedures. Among the practices that did 
Table 2 Transformation Components and Costs

\begin{tabular}{|c|c|c|c|c|c|}
\hline & \multicolumn{2}{|c|}{ Transformation components } & \multicolumn{3}{|l|}{ Transformation costs } \\
\hline & $\begin{array}{l}\text { Proportion } \\
\text { of practices } \\
\text { participating in } \\
\text { transformation } \\
\text { activities }\end{array}$ & $\begin{array}{l}\text { Major transformation } \\
\text { activities }\end{array}$ & $\begin{array}{l}\text { Costs per clinician, } \\
\text { median (range) }\end{array}$ & $\begin{array}{l}\text { Costs per patient, } \\
\text { median (range) }\end{array}$ & $\begin{array}{l}\text { Total costs per practice, } \\
\text { median (range) }\end{array}$ \\
\hline $\begin{array}{l}\text { One-time } \\
\text { transformation } \\
\text { activities }\end{array}$ & $100 \%(n=10)^{\dagger}$ & $\begin{array}{l}\text { - Prepare medical home } \\
\text { infrastructure (e.g., setting up } \\
\text { and verifying the accuracy of } \\
\text { patient registries, employee } \\
\text { training sessions to use quality } \\
\text { reporting systems, preparing } \\
\text { internal policies and procedures } \\
\text { for medical home transformation, } \\
\text { medical home recognition } \\
\text { applications) }(n=10) \\
\text { - Upgrade EHR software }(n=4)\end{array}$ & $\begin{array}{l}\$ 9814 \\
(\$ 1497-57,476)\end{array}$ & $\$ 5(\$ 1-77)$ & $\$ 30,991(\$ 7694-117,810)$ \\
\hline \multicolumn{6}{|c|}{ Ongoing transformation activities* } \\
\hline $\begin{array}{l}\text { Care management } \\
\text { activities }\end{array}$ & $100 \%(n=12)$ & $\begin{array}{l}\text { New staff hiring } \\
\text { - Care manager ( } n=9 \text {, average } \\
\text { of } 0.87 \text { FTEs per practice) } \\
\text { - Other staff (e.g., medical } \\
\text { assistant, nurse, social worker, } \\
\text { pharmacist; } n=5 \text {, average of } \\
0.98 \text { FTEs per practice) } \\
\text { New activities for current staff } \\
\text { - Care management meetings } \\
(n=5) \\
\text { - Patient outreach (e.g., } \\
\text { appointment reminders, } \\
\text { vaccination and routine } \\
\text { test reminders; } n=5) \\
\text { - Hospital and emergency room } \\
\text { transition phone calls }(n=3) \\
\text { - Patient education (e.g., } \\
\text { self-management of chronic } \\
\text { diseases; } n=2)\end{array}$ & $\begin{array}{l}\$ 29,457 \\
(\$ 11,420-78,182)\end{array}$ & $\$ 16(\$ 3-110)$ & $\$ 113,031(\$ 41,191-234,547)$ \\
\hline $\begin{array}{l}\text { General QI } \\
\text { activities }\end{array}$ & $92 \%(n=11)$ & $\begin{array}{l}\text { - Quality measurement, reporting, } \\
\text { and tracking }(n=10) \\
\text { - Physician care reminders }(n=8) \\
\text { - Team meetings }(n=6)\end{array}$ & $\begin{array}{l}\text { All practices: } \\
\$ 5765(\$ 0-29,924) \\
\text { Among those making } \\
\text { investment: } \\
\$ 6390(\$ 1250-29,924)\end{array}$ & $\begin{array}{l}\text { All practices: } \\
\$ 3(\$ 0-26) \\
\text { Among those } \\
\text { making investment: } \\
\$ 4(\$ 1-26)\end{array}$ & $\begin{array}{l}\text { All practices: } \\
\$ 23,734(\$ 0-63,905) \\
\text { Among those making } \\
\text { investment: } \\
\$ 29,994(\$ 2500-63,905)\end{array}$ \\
\hline $\begin{array}{l}\text { Expanded } \\
\text { access }\end{array}$ & $33 \%(n=4)$ & - Increased office hours $(n=3)$ & $\begin{array}{l}\text { All practices: } \\
\$ 0.00(\$ 0-28,151) \\
\text { Among those making } \\
\text { investment: } \\
\$ 26,637(\$ 2382-28,151)\end{array}$ & $\begin{array}{l}\text { All practices: } \\
\$ 0(\$ 0-18) \\
\text { Among those } \\
\text { making investment: } \\
\$ 14(\$ 1-18)\end{array}$ & $\begin{array}{l}\text { All practices: } \\
\$ 0(\$ 0-168,905) \\
\text { Among those making } \\
\text { investment: } \\
\$ 79,561(\$ 11,910-168,905)\end{array}$ \\
\hline Expanding IT & $33 \%(n=4)$ & $\begin{array}{l}\text {-Yearly maintenance and updates } \\
\text { of } \mathrm{EHRs}^{\S}(n=4)\end{array}$ & $\begin{array}{l}\text { All practices: } \\
\$ 0(\$ 0-20,069) \\
\text { Among those making } \\
\text { investment: } \\
\$ 3339(\$ 173-20,069)\end{array}$ & $\begin{array}{l}\text { All practices: } \\
\$ 0(\$ 0-10) \\
\text { Among those } \\
\text { making investment: } \\
\$ 7(\$ 4-10)\end{array}$ & $\begin{array}{l}\text { All practices: } \\
\$ 0(\$ 0-40,138) \\
\text { Among those making } \\
\text { investment: } \\
\$ 19,190(\$ 1733-40,138)\end{array}$ \\
\hline Other costs & $42 \%(n=5)$ & $\begin{array}{l}\text { - Hire other staff (e.g., consultants, } \\
\text { accounting services, increasing } \\
\text { physician work hours; } n=3 \text {, } \\
\text { average of } 0.55 \text { FTEs) } \\
\text { - Staff training }(n=2)\end{array}$ & $\begin{array}{l}\text { All practices: } \\
\$ 0 \text { (\$0-55,467) } \\
\text { Among those making } \\
\text { investment: } \\
\$ 2459(\$ 601-55,467)\end{array}$ & $\begin{array}{l}\text { All practices: } \\
\$ 0(\$ 0-22) \\
\text { Among those } \\
\text { making investment: } \\
\$ 2(\$ 1-22)\end{array}$ & $\begin{array}{l}\text { All practices: } \\
\$ 0 \text { (\$0-83,200) } \\
\text { Among those making } \\
\text { investment: } \\
\$ 9000(\$ 6013-83,200)\end{array}$ \\
\hline \multicolumn{3}{|c|}{ Total Median Yearly Ongoing Costs" } & $\$ 64,768(\$ 18,585-93,856)$ & $\$ 30(\$ 8-135)$ & $\$ 147,573(\$ 83,829-346,603)$ \\
\hline
\end{tabular}

* Ongoing costs were measured on a yearly basis

${ }^{\dagger}$ We were unable to collect one-time activities for two of the practices

${ }^{*}$ For practices that hired care managers, these new staff members performed many of these same activities. Therefore, activities performed by newly hired care managers were "rolled into" the care manager hiring

${ }^{\S}$ We were unable to collect IT-related costs for some system-affiliated practices because these costs were incurred at a higher organizational level

"This median does not represent the sum of categories above

expand access, the associated median yearly costs were $\$ 79,561$ (range, $\$ 11,910$ to $\$ 168,905$ ), or $\$ 26,637$ per clinician (\$2382 to $\$ 28,151$ ) and $\$ 14$ per patient (\$1 to $\$ 18$ ).

Nearly all practices reported that high-functioning IT systems were critical to providing patient care, but only four practices made ongoing investments in IT capabilities specifically related to medical home transformation. Among these four practices, median yearly costs of these investments were $\$ 19,190$ (range, $\$ 1733$ to $\$ 40,138$ ) or $\$ 3339$ per clinician $(\$ 173$ to $\$ 20,069)$ and $\$ 6.93$ per patient (\$3.83 to $\$ 10.03)$. In general, this money was 
spent on maintenance and upgrades of electronic health records (EHRs). The remaining eight practices reported making IT investments for other reasons, such as efforts to qualify for Meaningful Use incentives; these investments were not counted as costs of medical home transformation.

\section{Costs Incurred by Different Types of Practices}

Practices that experienced high transformation had median one-time per-clinician costs of $\$ 12,599$ (range, $\$ 3166$ to $\$ 57,476$ ), greater than the median cost of $\$ 2564$ (\$1497 to $\$ 19,635)$ observed among practices with low or moderate transformation (Table 3). However, ongoing yearly costs per clinician were similar between high transformers (median $\$ 56,842$; range, $\$ 24,668$ to $\$ 93,856$ ) and low to moderate transformers (median $\$ 65,668$; range, $\$ 18,585$ to $\$ 84,289)$.

We also observed cost differences between practices with differing system affiliation and practice size. Median total onetime costs for system-affiliated practices were $\$ 3165$ per clinician (range, $\$ 1498$ to $\$ 12,599$ ), compared to $\$ 19,635$ per clinician (\$7030 to $\$ 57,476)$ for independent practices, while median

Table 3 Median Costs by Practice Characteristic

\begin{tabular}{|c|c|c|}
\hline & $\begin{array}{l}\text { Extent of transformation } \\
\text { Moderate and Low } \\
(n=4 \text { practices })\end{array}$ & $\begin{array}{l}\text { High } \\
(n=8 \text { practices })\end{array}$ \\
\hline \multicolumn{3}{|l|}{ One-time costs } \\
\hline Per Clinician & $\begin{array}{l}\$ 2564 \\
(\$ 1497-19,635)\end{array}$ & $\begin{array}{l}\$ 12,599 \\
(\$ 3165-57,476)\end{array}$ \\
\hline Per Patient & $\begin{array}{l}\$ 2 \\
(\$ 1-13)\end{array}$ & $\begin{array}{l}\$ 9 \\
(\$ 1-30)\end{array}$ \\
\hline \multicolumn{3}{|l|}{ Ongoing costs } \\
\hline Per Clinician & $\begin{array}{l}\$ 65,668 \\
(\$ 18,585-84,289)\end{array}$ & $\begin{array}{l}\$ 56,842 \\
(\$ 24,668-93,856)\end{array}$ \\
\hline \multirow[t]{2}{*}{ Per Patient } & $\begin{array}{l}\$ 30 \\
(\$ 24-38)\end{array}$ & $\begin{array}{l}\$ 31.36 \\
(\$ 8-136)\end{array}$ \\
\hline & $\begin{array}{l}\text { Practice affiliation } \\
\text { System-affiliated } \\
(n=7 \text { practices })\end{array}$ & $\begin{array}{l}\text { Independent } \\
(n=5 \text { practices })\end{array}$ \\
\hline \multicolumn{3}{|l|}{ One-time costs } \\
\hline Per Clinician & $\begin{array}{l}\$ 3165 \\
(\$ 1498-12,599)\end{array}$ & $\begin{array}{l}\$ 19,635 \\
(\$ 7030-57,476)\end{array}$ \\
\hline Per Patient & $\begin{array}{l}\$ 2 \\
(\$ 1-9)\end{array}$ & $\begin{array}{l}\$ 16 \\
(\$ 7-30)\end{array}$ \\
\hline \multicolumn{3}{|l|}{ Ongoing costs } \\
\hline Per Clinician & $\begin{array}{l}\$ 41,914 \\
(\$ 18,585-91,025)\end{array}$ & $\begin{array}{l}\$ 71,769 \\
(\$ 24,668-93,856)\end{array}$ \\
\hline \multirow[t]{3}{*}{ Per Patient } & $\begin{array}{l}\$ 24 \\
(\$ 8-\$ 66)\end{array}$ & $\begin{array}{l}\$ 38 \\
(\$ 25-\$ 136)\end{array}$ \\
\hline & \multicolumn{2}{|c|}{ Number of primary care clinicians } \\
\hline & $\begin{array}{l}\text { Fewer than } 4 \text { primary care } \\
\text { clinicians }(n=6 \text { practices })\end{array}$ & $\begin{array}{l}4 \text { or more primary care } \\
\text { clinicians ( } n=6 \text { practices) }\end{array}$ \\
\hline \multicolumn{3}{|l|}{ One-time costs } \\
\hline Per Clinician & $\begin{array}{l}\$ 14,249 \\
(\$ 2565-57,476)\end{array}$ & $\begin{array}{l}\$ 5990 \\
(\$ 1497-23,542)\end{array}$ \\
\hline Per Patient & $\begin{array}{l}\$ 16 \\
(\$ 1-30)\end{array}$ & $\begin{array}{l}\$ 5 \\
(\$ 1-16)\end{array}$ \\
\hline \multicolumn{3}{|l|}{ Ongoing costs } \\
\hline Per Clinician & $\begin{array}{l}\$ 78,929 \\
(\$ 41,914-93,856)\end{array}$ & $\begin{array}{l}\$ 28,730 \\
(\$ 18,585-78,749)\end{array}$ \\
\hline Per Patient & $\begin{array}{l}\$ 35.88 \\
(\$ 21-136)\end{array}$ & $\begin{array}{l}\$ 24.17 \\
(\$ 8-53)\end{array}$ \\
\hline
\end{tabular}

ongoing yearly costs were $\$ 41,914$ per clinician $(\$ 18,585$ to $\$ 91,025)$ versus $\$ 71,769$ (\$24,668 to $\$ 93,856)$, respectively. Median total one-time costs for small practices (fewer than four clinicians) were $\$ 14,569$ per clinician (range, $\$ 2565$ to $\$ 57,456$ ), compared to $\$ 5990$ (\$1497 to $\$ 23,542$ ) for large practices (four or more clinicians), while median ongoing yearly costs were $\$ 78,929$ per clinician $(\$ 41,914$ to $\$ 93,856)$ and $\$ 28,730$ (\$18,585 to $\$ 78,749)$, respectively.

\section{DISCUSSION}

In this study, we found that practices can incur substantial transformation costs as they participate in medical home pilots, and the ongoing costs associated with maintaining new capabilities far exceeded one-time costs. The median ongoing medical homeassociated cost observed in our sample $(\$ 64,768$ per primary care clinician per year) is equivalent to roughly $35 \%$ of the mean annual income for primary care physicians in Pennsylvania. ${ }^{20}$ These costs were significant, and posed challenges for their practices' transformation efforts. However, both one-time and ongoing costs of transformation varied widely among practices.

Consistent with the PACCI pilot goal of enhancing practices' care management capabilities, we found that the majority of ongoing costs were related to care management. In our sample, median practice spending on care management activities attributed to medical home transformation was $\$ 14$ per patient per year, or slightly more than $\$ 1$ per patient per month. These expenditures are less than the "care management fees" paid to practices participating in other medical home pilots (which have averaged $\$ 7$ per member per month) and the $\$ 40$ per member per month that Medicare now pays to provide enhanced care management services for beneficiaries with two or more chronic conditions. $^{15,21,22}$

Two key factors may account for the difference between the prevailing care management fees and the care management costs incurred by practices participating in our study. First, our perpatient costs are based on all patients in a practice's panel, rather than just those who have a specific payer (e.g., a payer participating in a medical home initiative who might need to crosssubsidize patients of non-participating payers) or who have multiple chronic conditions (e.g., those eligible for Medicare care management fees). Second, we estimated only those costs associated with changes to care management programs related to medical home transformation; we excluded the costs of sustaining any preexisting care management programs, which payers may rationally wish to subsidize.

Our findings suggest that medical home transformation can have especially challenging financial implications for small and independent practices, which incurred substantially higher perclinician total transformation costs. These observed cost differences may be partially explained by our study design: we performed interviews at the practice site level and did not interview managers of the larger organizations that contained the systemaffiliated practices. Therefore, transformation costs incurred at the system level may be underestimated. However, this finding is 
consistent with recent qualitative research suggesting that, given the relatively high cost of investment in needed equipment and staff, small and independent practices may feel pressure to join larger systems as alternative payment models (including but not limited to payment reforms accompanying medical home interventions) take hold. ${ }^{23}$

Our study has several limitations. First, medical home transformation for some practices occurred up to 5 years before the interviews were conducted, and inaccurate recall is possible, especially for initial one-time costs. However, ongoing cost estimates may be more accurately reported, because in most cases these ongoing costs were still being incurred at the time of our interviews. The inclusion of multiple respondents for most practices also may have strengthened the validity of cost estimates. Second, we studied a relatively small number of practices, precluding the possibility for meaningful statistical inference. However, our sample size was similar to, if not larger than, previous efforts to study other program implementation costs in primary care practices. ${ }^{24,25}$ Third, we do not have an explanation for why practices experiencing high and low transformation had similar ongoing costs of transformation. In light of the small number of practices studied and the lack of previous research on this topic, we believe that replication of this finding is necessary. Fourth, we studied practices that participated in just one medical home pilot. Our estimates of practice transformation costs may not generalize to medical home initiatives that take place in other contexts (e.g., other geographic areas or time periods) or that incorporate different intervention components (e.g., different medical home recognition criteria, types of technical assistance, or resources provided to participating practices). In particular, the costs of transformation could be higher (or lower) in interventions with more (or less) generous financial support for participating practices. Fifth, when estimating patient panel sizes, some practices consulted their billing systems (e.g., counting all patients for whom a bill was submitted within the past year), while others consulted EHR-based registries of current patients. These differences in counting methods may have contributed to the wide variation in panel size estimates.

\section{CONCLUSIONS}

Medical homes and other delivery system innovations will likely grow as payers like the Centers for Medicare and Medicaid Services increasingly emphasize value-based payment models. ${ }^{26}$ As policymakers consider how to financially support physician practices in their efforts to transform and thrive in a changing payment and policy environment, our findings from a medical home pilot may offer some useful guidance. We observed that costs of transformation were significant and highly variable across practices, meaning that a uniform per-clinician or perpatient subsidy may exceed investment costs for some practices and fall short for others. In particular, greater per-clinician subsidies to small and independent practices may be necessary if payers wish to avoid creating pressure for such practices to merge with larger delivery systems. Furthermore, because ongoing costs of maintaining a medical home are substantially larger than the one-time costs of transformation, payers may need to consider long time horizons for such subsidies. Continuing experimentation, evaluation, and refinement of medical home interventions can help solidify the business case for making such investments in primary care practices.

Acknowledgments: This study was sponsored by the Agency for Healthcare Research and Quality (1R03HSO02616-01). No sponsor had a role in the design or conduct of the study; collection, management, analysis, or interpretation of the data; or preparation, review, or approval of the manuscript. This paper was presented at the Academy Health Annual Research Meeting in 2015.

Corresponding Author: Grant R. Martsolf, PhD, MPH, RN; RAND Corporation, 20, Park Plaza, Pittsburgh, PA 02116, USA (e-mail: martsolf@rand.org).

Conflict of Interest: Dr. Friedberg has received compensation from the US Department of Veterans Affairs for consultation related to medical home implementation and research support from the PatientCentered Outcomes Research Institute via subcontract to the National Committee for Quality Assurance. No other author has a potential conflict of interest to disclose.

\section{REFERENCES}

1. Friedberg MW, Schneider EC, Rosenthal MB, Volpp KG, Werner RM. Association between participation in a multipayer medical home intervention and changes in quality, utilization, and costs of care. JAMA. 2014;311(8):815-25. doi:10.1001/jama.2014.353.

2. Jackson G, Powers BJ, Chatterjee R, Bettger J, Kemper A, Hasselblad V, Dolor R, Irvine J, Heidenfelder B, Kendrick A, Gray R, Williamns JV. The patient-centered medical home: A systematic review. Ann Intern Med. 2013;158(3): 169-78.

3. Werner RM, Duggan M, Duey K, Zhu J, Stuart EA. The patient-centered medical home: An evaluation of a single private payer demonstration in new jersey. Med Care. 2013;51(6):487-93. doi:10.1097/MLR.0b013e31828d4d29.

4. Peikes D, Zutshi A, Genevro JL, Parchman ML, Meyers DS. Early evaluations of the medical home: Building on a promising start. Am J Manag Care. 2012;18(2):105-16.

5. Rosenthal MB, Friedberg MW, Singer SJ, Eastman D, Li Z, Schneider EC. Effect of a multipayer patient-centered medical home on health care utilization and quality: The Rhode Island chronic care sustainability initiative pilot program. JAMA Intern Med. 2013;173(20):1907-13. doi:10.1001/jamainternmed.2013.10063.

6. Fifield J, Forrest DD, Martin-Peele M, Burleson JA, Goyzueta J, Fujimoto M, Gillespie W. A randomized, controlled trial of implementing the patient-centered medical home model in solo and small practices. J Gen Intern Med. 2013;28(6):770-7. doi:10.1007/s11606012-2197-z. PubMed PMID: 22956444, PubMed Central PMCID: PMC3663952.

7. Gilfillan RJ, Tomcavage J, Rosenthal MB, Davis DE, Graham J, Roy JA, Pierdon SB, Bloom FJ Jr, Graf TR, Goldman R, Weikel KM, Hamory BH, Paulus RA, Steele GD Jr. Value and the medical home: Effects of transformed primary care. Am J Manag Care. 2010;16(8):607-14.

8. Friedberg M, Rosenthal M, Werner R, Volpp K, Schneider E. Effects of a medical home and shared savings intervention on quality and utilization of care. JAMA Intern Med. 2015.

9. David G, Gunnarsson C, Saynisch PA, Chawla R, Nigam S. Do PatientCentered Medical Homes Reduce Emergency Department Visits? Health Serv Res. 2015;50(2):418-39. doi:10.1111/1475-6773.12218.

10. van Hasselt M, McCall N, Keyes V, Wensky SG, Smith KW. Total cost of care lower among medicare fee-for-service beneficiaries receiving care from patient-centered medical homes. Health Serv Res. 2015;50(1):253-72. doi:10.1111/1475-6773.12217. 
11. Paustian ML, Alexander JA, El Reda DK, Wise CG, Green LA, Fetters MD. Partial and incremental pcmh practice transformation: Implications for quality and costs. Health Serv Res. 2014;49(1):52-74. doi:10.1111/ 1475-6773.12085.

12. Alexander JA, Bae D. Does the patient-centred medical home work? A critical synthesis of research on patient-centred medical homes and patient-related outcomes. Health Serv Manag Res. 2012;25(2):51-9. doi:10.1258/hsmr.2012.012001.

13. Martsolf GR, Alexander JA, Shi Y, Casalino LP, Rittenhouse DR, Scanlon DP, Shortell SM. The patient-centered medical home and patient experience. Health Serv Res. 2012;47(6):2273-95. doi:10.1111/j.14756773.2012.01429.x.

14. Kern LM, Edwards A, Kaushal R. The patient-centered medical home, electronic health records, and quality of care. Ann Intern Med. 2014;160(11):741-9. doi:10.7326/m13-1798.

15. Edwards ST, Bitton A, Hong J, Landon BE. Patient-centered medical home initiatives expanded in 2009-13: Providers, patients, and payment incentives increased. Health Aff (Millwood). 2014;33(10):1823-31. doi: $10.1377 /$ hlthaff.2014.0351

16. Agency for Healthcare Research and Quality (AHRQ). Patient centered medical home resource center 2014. Available from: http://pcmh.ahrq. gov/page/federal-pcmh-activities. Accessed October 26, 2015.

17. Martsolf GR, Kandrack R, Schneider EC, Friedberg MW. Categories of practice transformation in a statewide medical home pilot and their association with medical home recognition. J Gen Intern Med. 2015. doi:10.1007/s11606-014-3176-3.

18. Kaplan RS. Cost \& effect: Using integrated cost systems to drive profitability and performance: Harvard Business Press; 1998.

19. Employee Benefit Research Institute. How much do benefits cost employers? Available from: http://www.ebri.org/publications/benfaq/index.cfm? fa=ovfaq1. Accessed October 26, 2015.

20. Bureau of Labor Statistics, U.S. Department of labor, occupational employment and wage estimates, Pennsylvania. 2013. Available from: http://www.bls.gov/oes/tables.htm. Accessed October 26, 2015.

21. American Academy of Family Physicians. Care management fees 2014 Available from: http://www.aafp.org/about/policies/all/care-management.html. Accessed October 26, 2015

22. Edwards ST, Landon BE. Medicare's chronic care management payment — payment reform for primary care. N Engl J Med. 2014;371(22):2049-51. doi:10.1056/NEJMp1410790.

23. Friedberg MW, Chen PG, White C, Jung O, Raaen L, Hirshman S, Hoch E, Stevens C, Ginsburg PB, Casalino LP, Tutty M, Vargo C, Lipinski L. Effects of health care payment models on physician practice in the United States. Santa Monica, CA: RAND Coporation (RR-869-AMA), 2015. http:// www.rand.org/pubs/research_reports/RR869.html. Accessed November $11,2015$.

24. West DR, Radcliff TA, Brown T, Cote MJ, Smith PC, Dickinson WP. Costs associated with data collection and reporting for diabetes quality improvement in primary care practices: A report from snocap-USA. J Am Board Fam Med. 2012;25(3):275-82. doi:10. 3122/jabfm.2012.03.110049.

25. Halladay JR, Stearns SC, Wroth T, Spragens L, Hofstetter S, Zimmerman S, Sloane PD. Cost to primary care practices of responding to payer requests for quality and performance data. Ann Fam Med. 2009;7(6):495-503.

26. Burwell SM. Setting value-based payment goals-HHS efforts to improve U.S. Health care. N Engl J Med. 2015;372(10):897-9.

\section{APPENDIX A: METHODS ASSESSING STRUCTURAL AND FUNCTIONAL TRANSFORMATION}

\section{Structural transformation}

To gather data on practice structure, we mailed the survey to one leader from each of the 104 practices participating in the PACCI: once to assess structural capabilities at baseline (before the intervention began in the practice's region) and again to assess the same capabilities 3 years after the intervention had begun. Eighty-one practices responded to both the baseline and year 3 surveys (78\% response rate). Using the survey data, we calculated a Medical Home Structural Capability Score by calculating the proportion of 69 surveyed structural capabilities reported as being present in a responding practice. These 69 structural capabilities were drawn from across eight domains central to medical home models: use of shared communication with patients (13 survey items), care managers, ${ }^{7}$ referral to community services, ${ }^{2}$ use of electronic health records ${ }^{20}$ care reminders, ${ }^{11}$ performance feedback to providers, ${ }^{10}$ patient registries, ${ }^{4}$ and after-hours care. ${ }^{2}$ We then calculated "transformation" as the pre- to postdemonstration change in each practice's Medical Home Capability Score. Further details of this scoring method are published elsewhere. ${ }^{1}$

\section{Functional transformation}

We assessed functional transformation based on pre- and postdemonstration changes in measures of quality and costs using health insurance claims data. These claims data were collected from 8 of the 12 health plans participating in the PACCI for a 4.5to 5 -year period (1.5 to 2 years pre-intervention and 3 years postintervention). To classify practices on quality transformation, we calculated pre- to post-intervention changes in each practice's performance on a global composite measure, computed as the equally weighted mean of nine individual process measures of quality. The measures were calculated using the following specifications presented in Table 4.

To classify practices on costs of care, we calculated total costs per patient in each month. For both the quality and cost measure, we included only patients that were continuously enrolled through the entire study period.

Table 4 Quality Measure Specifications

\section{Quality measures}

\begin{tabular}{|c|c|}
\hline Measure name & Definition* \\
\hline Breast Cancer Screening & $\begin{array}{l}\text { Percentage of women aged } 40-69 \text { years } \\
\text { who had at least one mammogram in the } \\
\text { measurement year or year prior to the } \\
\text { measurement year }\end{array}$ \\
\hline Cervical Cancer & Percentage of women aged 21-64 years who \\
\hline Screening & $\begin{array}{l}\text { had at least one Pap test in the measurement } \\
\text { year or } 2 \text { years prior to the measurement year }\end{array}$ \\
\hline Colorectal Cancer & Percentage of adults 50 to 80 years of age \\
\hline Screening & $\begin{array}{l}\text { who had one or more of the following during } \\
\text { the measurement year: fecal occult blood } \\
\text { test, flexible sigmoidoscopy, double contrast } \\
\text { barium enema or air contrast barium enema, } \\
\text { or colonoscopy }\end{array}$ \\
\hline Chlamydia Screening & $\begin{array}{l}\text { Percentage of sexually active women ages } 16 \\
\text { to } 24 \text { who had at least one test for chlamydia } \\
\text { during the measurement year }\end{array}$ \\
\hline \multirow{2}{*}{$\begin{array}{l}\text { Comprehensive Diabetes } \\
\text { Care: HbA1c Testing }\end{array}$} & Percentage of patients aged $18-75$ years \\
\hline & $\begin{array}{l}\text { with diabetes (type } 1 \text { and type } 2 \text { ) who had a } \\
\text { hemoglobin A1c test during the measurement } \\
\text { year }\end{array}$ \\
\hline \multirow{2}{*}{$\begin{array}{l}\text { Comprehensive Diabetes } \\
\text { Care: Eye Exams }\end{array}$} & Percentage of patients aged $18-75$ years with \\
\hline & $\begin{array}{l}\text { diabetes (type } 1 \text { and type } 2 \text { ) who had a } \\
\text { retinal or dilated eye exam by an eye care } \\
\text { professional in the measurement year or a } \\
\text { negative retinal exam (no evidence of } \\
\text { retinopathy) by an eye care professional in } \\
\text { the measurement year }\end{array}$ \\
\hline Comprehensive Diabetes & Percentage of patients aged $18-75$ years with \\
\hline & diabetes (type 1 and type 2) who had a low- \\
\hline & $\begin{array}{l}\text { density lipoprotein cholesterol test during the } \\
\text { measurement year }\end{array}$ \\
\hline
\end{tabular}

(continued on next page) 
Table 4. (continued)

\begin{tabular}{ll}
\hline \hline Quality measures & Definition* \\
\hline Measure name & $\begin{array}{l}\text { Percentage of patients aged 18-75 years with } \\
\text { diabetes (type 1 and type 2) who received } \\
\text { nephropathy screening, had a nephrologist } \\
\text { visit, or had evidence of nephropathy as } \\
\text { documented through administrative data } \\
\text { Diabetic Nephrop }\end{array}$ \\
$\begin{array}{l}\text { Use of Apring the measurement year } \\
\text { Medications for People }\end{array}$ & $\begin{array}{l}\text { Percentage of patients aged 5-56 years of } \\
\text { age during the measurement year who were } \\
\text { identified as having persistent asthma and } \\
\text { who were appropriately prescribed } \\
\text { medication during the measurement year }\end{array}$ \\
\hline
\end{tabular}

Definitions taken from National Committee for Quality Assurance (NCQA). HEDIS 2009. Health plan employer data \& information set. Vol. 2, Technical specifications. Washington (DC): National Committee for Quality Assurance (NCQA); 2009. Detailed lists of comorbid conditions, competing diagnoses, and other exclusion criteria are contained in the original measure documentation available from the NCQA

* One of the health plans contributed only 18 months of pre-intervention claims data. Therefore, all quality measures for this plan were calculated using an 18-month look-back period (rather than 2 years) when applicable

\section{APPENDIX B: INTERVIEW PROTOCOL}

\section{Respondent ID:}

\section{INTRODUCTION AND PURPOSE OF THE INTERVIEW}

Before we get started, I'd like to briefly review the purpose of this interview and the confidentiality provisions that were described in detail in the email we sent you.

- As you know, a number of payers are incentivizing primary care practices to adopt characteristics of patientcentered medical homes (PCMH). Although these payers pay enhanced fees in order to compensate practices for transforming, little is known about the actual costs of transformation. The purpose of this project is to estimate the costs associated with transformation.

- We've come to you so that you can help us understand how primary care practices transform to be more in line with the PCMH model.

- We would like to ask you about the impact of transformations on the delivery of care and how these transformations translate into practice costs.

We are going to begin by asking you to discuss changes in your practices that were related to the PACCI initiative. We know that this transformation happened nearly 4 years ago, but we ask you to describe and estimate as closely as possible. We will also ask you general questions about practices that you have adopted since that transformation occurred. But for the initial questions, I'd like you to focus on just those changes that were influenced by the PACCI initiative. We will start with a general overview of your practice and then move to talk about the changes that have occurred in your practice as a result of the PACCI initiative. We sent you some materials beforehand that outlined the discussion topics. Do you have any questions before we proceed?

\section{Respondent Background}

1. We understand that you are the _title/position] in _practice name]. Is that correct?

2. What is your professional background? [If physician:] Are you a primary care physician or some other kind of specialist? [If other specialist:] What is your specialty?

3. How long have you been working at [practice name]?

4. How long have you been the [title/position]?

\section{Practice history}

During this section of the interview, I'd like to talk about changes that have occurred at your practice within the last 5 years. We have special interest in patient-centered medical home (PCMH), but we would like to hear about all of the changes to better situate PCMH-related efforts with other key initiatives. So, first, I want to get a general sense of how the practice has changed over the last 5 years. I know that this spans a long time, so you'll just have to try your best.

1. Please first tell me a little bit about the history of your practice.

a. How did it start?

b. Who were the formative providers and managers?

c. How long has it been around?

d. How has the organization changed generally over that time?

\section{Changes over time}

I'd now like to discuss how the practice has changed. Let's start with a broad discussion of changes and then move to specifics. For example, if over the course of the last 5 years the organization brought on non-physician care managers, we will talk specifically about that and dig deep. Again, we want to put this in context of the PACCI program. So, we'll set an anchor point at MONTH:YEAR. We'll talk about changes that occurred before and after that date. Again, I know that was a long time ago, but try your best to remember the details.

2. How has the structure and organization of your practice changed over the last 5 years?

a. When would you say that change occurred?

b. What was the impetus for this change?

[PROMPT: If interviewee gets stuck at any point, lead with questions related to categories of change often associated with PCMH transformation including: enhanced patient outreach \& community involvement, non-physician care managers, teambased care, developing quality infrastructure, expanded hours, and EHR] 


\section{Describing change}

[NOTE: After all of the changes have occurred, run through all of these questions for every change mentioned by the interviewee.] Let's talk more specifically about that change.

1. To what extent were these changes related to PCMH/PACCI implementation?

a. Would you have definitely made these changes regardless of the PACCI initiative (i.e., these changes were already in place and the PACCI had no effect on it)?

b. Did it happen only because of the PACCI initiative (i.e., definitely would not have happened without the PACCI)?

2. What percentage of those costs was due to the PACCI? What specific changes did the practice have to make in order to put these changes into place?

a. Who participated in enacting these changes? What were their job titles?

b. How much staff time and effort do you think it required to put these changes into place? (Prompts: staff time spent on planning for extended hours, consultant or contractor costs?)

c. Were there any other non-staff-related expenses related to this improvement? How much would you estimate those to be? (Prompts: new promotional materials, advertising changes?)

d. What percentage of those costs associated with these changes was due to the PACCI?

3. Are these changes still in place?

a. Who participates in this program?

b. What are their job titles?

c. Approximately how many hours per week do staff work executing this program? Are there extra staffing costs related to the program (i.e., overtime)?

d. Are there any other ongoing non-staff-related expenses associated with this program (i.e., materials, capital expenses, etc.)?

4. If not, when did this program discontinue? Why did it discontinue?

a. Why did this program end?

b. Who participated in this program?

c. What were their job titles?

d. Approximately how many hours per week did staff work executing this program? Were there extra staffing costs related to the program (i.e., overtime)?

e. Were there any other on-going non-staff-related expenses associated with having extended hours?
[Once all changes have been described in detail, move to "Other transformation costs."]

Other transformation costs

Finally, I want to talk about any other changes that you made or expenses that you incurred related to the PACCI initiative. These expenses might include hiring consultants to help your transform or any other time and materials spent during the transformation process.

1. If so, what specific changes to practice infrastructure were required to put these changes into place?

a. Who participated in enacting these changes? What were their job titles?

b. How much staff time and effort do you think it required to put these into place?

c. Were there any other non-staff-related expenses related to this improvement? How much would you estimate those to be?

d. What percentage of those costs associated with these changes was due to the PACCI?

2. Are these systems still in place?

a. If so, what is the process for executing these shared communication systems every week?

i. Who works on it?

ii. What are their job titles?

iii. Approximately how many hours per week do they spend on this activity?

iv. If this change were not in place, what staff duties would they have been doing instead?

v. What did the practice do before this change was put in place?

vi. Were there any other non-staff-related expenses such as materials or IT?

\section{Conclusion and feedback}

This concludes the interview. Thank you for your time and insight into your practice's transformation over the last 5 years. We would greatly appreciate if you could give us some brief feedback on the interview so that we may improve moving forward.

1. What were the biggest challenges in answering these questions?

2. Is there anything we can do to better facilitate the interview?

\section{REFERENCES}

1. Martsolf GR, Kandrack R, Schneider EC, Friedberg MW. Categories of Practice Transformation in a Statewide Medical Home Pilot and their Association with Medical Home Recognition. J Gen Intern Med. Feb 112015. 